\title{
PRODUCTION AND CHARACTERIZATION OF BIOSURFACTANTS PRODUCED BY Pseudomonas aeruginosa B031 ISOLATED FROM A HYDROCARBON PHYTOREMEDIATION FIELD
}

\author{
ENDAH RETNANINGRUM ${ }^{1 *}$ and WAHYU WILOPO ${ }^{2}$ \\ ${ }^{1}$ Faculty of Biology, Universitas Gadjah Mada, Yogyakarta 55281, Indonesia \\ ${ }^{2}$ Department of Geological Engineering, Faculty of Engineering, Universitas Gadjah Mada, \\ Yogyakarta 55281, Indonesia
}

Received 31 January 2017 / Accepted 29 January 2018

\begin{abstract}
The biosurfactants are used by several industrial sectors such as petroleum, agriculture, food production, chemistry, cosmetics, and pharmaceuticals. Because of their hydrophobic and hydrophilic moieties, they have potency to reduce surface tension, interfacial tension between water-hydrocarbon systems, and low micelle concentration. Their characteristics strongly depend on the producer strain as well as on the medium composition, such as carbon and nitrogen sources. This study was conducted to investigate the influence of different sources of carbon (n-hexadecane, glycerol and glucose) and nitrogen (urea, $\mathrm{NH}_{4} \mathrm{Cl}$ and $\mathrm{NaNO}_{3}$ ) for the production of biosurfactants by a new strain of Pseudomonas aeruginosa B031 isolated from a rhizosphere of Paraserianthes falcataria L. Nielsen, a hardwood plant species at a phytoremediation field. The biosurfactant characteristics of the strain were evaluated, particularly its surface-active properties and potential to remove hydrocarbon. Glycerol was found to be the optimum carbon source, with rhamnose concentration, emulsification index, and critical micelle concentration (CMC) of $718 \mathrm{mg} / \mathrm{L}, 37 \%$, and 35 $\mathrm{mN} / \mathrm{m}$, respectively. Sodium nitrate $\left(\mathrm{NaNO}_{3}\right)$ was observed as the optimum nitrogen source, with rhamnose concentration, emulsification index, and CMC of $290 \mathrm{mg} / \mathrm{L}, 30 \%$, and $24 \mathrm{mN} / \mathrm{m}$, respectively. These biosurfactants efficiently reduced surface tension of culture broth from $42 \mathrm{mN} / \mathrm{m}$ to $31 \mathrm{mN} / \mathrm{m}$ for the glycerol treatment and from $37 \mathrm{mN} / \mathrm{m}$ to $24 \mathrm{mN} / \mathrm{m}$ for the sodium nitrate treatment. The crude biosurfactants from the glycerol and sodium nitrate treatments also removed $87.5 \%$ and $84 \%$, respectively, of crude oil from sand. These rates were higher than those of the chemical surfactants (SDS and Triton X-100). These findings indicate that the biosurfactants produced by the strain from both glycerol and $\mathrm{NaNO}_{3}$ treatments can efficiently decrease the interfacial tension of culture broth dilution and have a high emulsion index, thus hold promise in hydrocarbon bioremediation application.
\end{abstract}

Keywords: bioremediation, biosurfactant, glycerol, $\mathrm{NaNO}_{3}$, optimum

\section{INTRODUCTION}

Biosurfactants are amphiphatic compounds produced by a wide variety of microorganisms that either adhere to cell surface or are excreted extracellular in the growth medium (Al-Bahry et al. 2013; Geetha et al. 2018). They contain hydrophobic and hydrophilic moieties that reduce surface tension, interfacial tension between waterhydrocarbon systems, and low micelle concentration (Zdziennicka \& Jańczuk 2018). As such, biosurfactants are used by several industrial

\footnotetext{
* Corresponding author: endahr@ugm.ac.id
}

sectors such as petroleum, agriculture, food production, chemistry, cosmetics, and pharmaceuticals (Lai et al. 2009; PacwaPlociniczak et al. 2011). They could be used also to remove hydrocarbon contamination (Mnif \& Ghribi2015; Ma et al.2018).

Biosurfactants are composed of lipopeptides, glycolipids, phospholipids, fatty acids, neutral lipids, and polymeric biosurfactants (Moya et al. 2015). Often produced during the stationary phase of bacterial growth, they exhibit considerable substrate specificity (Calvo et al. 2009). Their characteristics strongly depend on the producer strain as well as on the medium 
composition, such as carbon and nitrogen sources (Janek et al.2010; Liu etal. 2015).

Microbial strains belonging to species Bacillus sp. (Barakat et al. 2017), Candida lipolytica (Rufino et al. 2011), Rhodococcus sp. (Shavandi et al. 2011), Pseudomas sp. (Thavasi et al. 2011; Sakthipriya et al. 2015) and Sphingobacterium detergens (Burgos-Diaz et al. 2013) have been reported to produce biosurfactants. Of these, the rhamnolipids biosurfactants produced by Pseudomonas sp. is of interest in that it could remove hydrocarbon contamination (Deepika et al. 2016; Ma et al. 2016; Ma et al.2018). Due to economic considerations in the industry, biosurfactants are commonly applied as whole-cells culture or crude biosurfactant. As reported by Patowary et al. (2018), purification process of biosurfactants consumed almost $60 \%$ of the total production costs.

A phytoremediation field in Balikpapan, East Kalimantan, Indonesia, uses Paraserianthes falcataria L. Nielsen, a hardwood plant species, for hydrocarbon removal. Previous studies show that plants for phytoremediation could remove hydrocarbon pollutants through mechanisms such as biodegradation, phytovolatilization, accumulation, and transformation (Kong et al. 2016; Guo et al. 2017). When soil hydrocarbon concentration in the phytoremediation field was measured in May 2014, it was found that the plants removed $50 \%$ of the hydrocarbon pollution within 3 months. In comparison, other hardwood plants, such as Tectona grandis and Gmelina arborea, are reported to remove only $10 \%$ and $15 \%$, respectively (Agbogidi et al. 2007; Yenn et al.2014). The differences in the hydrocarbon removal ability are influenced by the plant species, which create unique habitats for the soil microbial population (Cristaldi et al. 2017). That is, the soil microbial population is strongly influenced by the plant species used for phytoremediation.

The process of removing hydrocarbon in a phytoremediation field results from the complex interaction between roots, rhizosphere and soil microorganisms (Khan et al. 2013; Fatima et al. 2018). These association induce the particular physiology and biochemistry of plant roots, resulting in the process of hydrocarbons removal. As such, phytoremediation processes can make nutrients available, such as carbon and nitrogen (Hou et al. 2015). Glucose, a carbon source, is produced during photosynthesis, and is exuded into the soil by plant roots (Khan et al. 2013). On other hand, the degradation process of hydrocarbon contamination in the soil environment induces $\mathrm{n}$-hexadecane and glycerol, which are carbon sources also (Varjani 2017). During the phytoremediation process, adding $\mathrm{N}$ fertilizer (e.g., urea, $\mathrm{NH}_{4} \mathrm{Cl}, \mathrm{NaNO}_{3}$ ) enhances hydrocarbon degradation because nitrogen becomes available to both plant and soil microorganism.

A strain of Pseudomonas aeruginosa B031, which was isolated from the rhizosphere of Paraserianthes falcataria L. Nielsen, probably has unique characters, as shown by Thavasi et al. (2011) and Sakthipriya et al. (2015), especially in terms of biosurfactant production. In this regard, it is important to investigate the medium compositions involving variations in carbon sources (n-hexadecane, glycerol, and glucose) and nitrogen sources (urea, $\mathrm{NH}_{4} \mathrm{Cl}$ and $\mathrm{NaNO}_{3}$ ) for the production of biosurfactants by Pseudomonas aeruginosa $\mathrm{B} 031$. The characteristics of the strain were evaluated, particularly its surface-active properties and potential to remove hydrocarbons.

\section{MATERIALS AND METHODS}

\section{Biosurfactant-producing Bacterial Strain}

A biosurfactant-producing bacterial strain belonging to Pseudomonas aeruginosa B031 was isolated from a hydrocarbon phytoremediation field in Balikpapan, East Kalimantan, Indonesia. The strain was isolated and screened using methods described by Hassanshahian and Emitazi (2008). It was identified following the methods described in Bergey's Manual Systematic of Bacteriology (Brenner et al. 2005). This bacterial isolate was then sub-cultured on Luria Bertani medium agar tubes as a stock culture before use as inoculum.

\section{Inoculum Propagation}

The strain stock culture of $P$. aeruginosa B031 was inoculated into a plate containing Luria Bertani and incubated at $37^{\circ} \mathrm{C}$. After $24 \mathrm{~h}$, one loop of culture was inoculated to $50 \mathrm{~mL}$ of Stone Mineral Salt Solution (SMSS) medium in a $250 \mathrm{~mL}$ Erlenmeyer flask. The culture was then incubated at $37^{\circ} \mathrm{C}$ for $18 \mathrm{~h}$ and agitated at $200 \mathrm{rpm}$ in a shaking incubator (Thorsen et al. 2013). At the end of the incubation period, a culture sample 
was taken and adjusted with sterile SMSS medium in order to obtain a cell suspension of $0.7 \mathrm{OD}$ (optical density), determined by a spectrophotometer. The number of bacterial cells corresponded to an inoculum of $10^{7} \mathrm{CFU} / \mathrm{ml}$. The SMSS medium used for these experiments consisted of the following $\left(\mathrm{g} \mathrm{L}^{-1}\right): 0.05 \% \mathrm{KH}_{2} \mathrm{PO}_{4}$, $0.1 \% \mathrm{~K}_{2} \mathrm{HPO}_{4}, 0.05 \%, \mathrm{MgSO}_{4} .7 \mathrm{H}_{2} \mathrm{O}, 0.01 \% \mathrm{KCl}$, and $0.001 \% \mathrm{FeSO}_{4} \cdot 7 \mathrm{H}_{2} \mathrm{O}$; the $\mathrm{pH}$ was adjusted to 7.0 by $1.0 \mathrm{M} \mathrm{HCl}(\mathrm{pH} 7.2)$.

\section{Optimization of Medium and Cultivation Condition}

The influence of carbon and nitrogen sources on the biosurfactant yield and its properties was studied in the SMSS medium supplemented with $2 \%(\mathrm{v} / \mathrm{v})$ of their sources. The carbon sources were $n$-hexadecane, glycerol, and glucose. The nitrogen sources were urea, $\mathrm{NH}_{4} \mathrm{Cl}$ and $\mathrm{NaNO}_{3}$. A $2 \%$ cell suspension of $0.7 \mathrm{OD}$ at $600 \mathrm{~nm}$ was inoculated into a $500-\mathrm{ml}$ flask containing $100 \mathrm{~mL}$ SMSS medium. The culture was then incubated at $37^{\circ} \mathrm{C}$ under agitation of $200 \mathrm{rpm}$. After 96 hours of incubation, culture samples were collected and further evaluated for bacterial biomass and biosurfactant characteristics.

\section{Biomass and Biosurfactant Characteristics}

The culture samples collected previously were centrifuged at $36,000 \mathrm{~g}$, temperature of $4^{\circ} \mathrm{C}$ for $1 \mathrm{~h}$. The pellet cells were dried overnight at $105^{\circ} \mathrm{C}$ and then weighed to measure the Pseudomonas aeruginosa $\mathrm{B} 031$ biomass. The crude biosurfactants in the cell-free culture medium obtained were characterized in terms of rhamnose concentration and surface-active properties, including emulsification index (E24), surface tension, and critical micelle concentration (CMC).

\section{Rhamnose Concentration}

Rhamnose concentration in the cell-free culture medium was measured using the phenolsulphuric method (Seedevi et al. 2018). One $\mathrm{mL}$ of the cell-free culture broth was mixed with $0.5 \mathrm{~mL}$ of $80 \%$ phenol and $2.5 \mathrm{ml}$ of concentrated sulphuric acid. After the mixture was incubated for $10 \mathrm{~min}$ at room temperature, the absorbance was measured at $490 \mathrm{~nm}$ using a spectrophotometer. The rhamnose concentration was then calculated using a standard curve prepared using different concentrations of rhamnose (Vinogradov et al. 2016).

\section{Emulsification Index (E24)}

The emulsification index of the culture samples was determined using the method described by Panjiar et al. (2015). Two $\mathrm{ml}$ of hexadecane and $2 \mathrm{ml}$ of the cell free supernatant were mixed in a test tube and homogenized in a vortex at 3,500 rpm high speed for $2 \mathrm{~min}$. The emulsification stability was measured after $24 \mathrm{~h}$. The emulsification index was calculated as follows:

$$
\text { E24 }=\frac{\text { Height of emulsion formed }(\mathrm{cm})}{\text { Total height of solution }(\mathrm{cm})} \times 100
$$

\section{Surface Tension Measurement}

The surface tension of the cell-free supernatant was measured in a K6 tensiometer (Shimadzu), using the du Nouy ring method. The values reported are the mean of three measurements (Joshi \& Shekhawat 2014).

\section{Critical Micelle Concentration (CMC)}

Cell-free culture media of different carbon and nitrogen sources were diluted into various extents with sterile medium to analyze for surface tension $(1 / 128,1 / 64,1 / 32,1 / 16,1 / 8,1 / 4,1 / 2$, and 1). The dilutions at which a surfactant begins to aggregate and had no further significant reduction in surface tension were assessed as CMCs. These measurements were estimated graphically by plotting the surface tension values versus the culture broth dilution values (Cheng 2013).

\section{Hydrocarbon Removal Ability}

The potential of the crude biosurfactant to remove hydrocarbons from contaminated sand was evaluated using the methodology described by Aparna et al. (2012). Sandy soil samples were collected from the Parangtritis Beach, Indonesia; the samples were air dried and then sieved using a 2-mm mesh. Furthermore, samples were mixed with tap water up to the moisture content $19 \%$ (v/w). Soil samples (20 g each) were polluted by 2 $\mathrm{g}$ of crude oil (Pertamina, Balongan, Cilacap, Indonesia), then transferred to $250-\mathrm{mL}$ Erlenmeyer flasks. The flask was added with 40 $\mathrm{mL}$ of the cell-free fermented broth and then 
incubated at $37^{\circ} \mathrm{C}$ under agitation of $200 \mathrm{rpm}$ in a shaking incubator. After $18 \mathrm{~h}$ incubation, the sample was added with $120 \mathrm{~mL}$ of dichloromethane as the extracting solvent, then centrifuged at $10,000 \times \mathrm{g}$ for $15 \mathrm{~min}$. The amount of residual hydrocarbon in the sample was determined by gravimetric analysis (Villalobos et al. 2008). For comparison, the hydrocarbon removal ability of SDS, Triton X-100 and distilled water (control) was also analyzed under the same conditions.

\section{Statistical Analysis}

All statistical analyses were performed using Stat View for Windows (SAS Institute, Cary, NC, USA) based on $\mathrm{P}<0.05$. The effects of the treatments and their differences were assessed using analysis of variance (ANOVA) and Duncan Multiple Range Test (DMRT) method, respectively.

\section{RESULTS AND DISCUSSION}

\section{Bacterial Strain Identification}

Table 1 lists the morphological, cultural, and biochemical characteristics of the bacterial strain selected for this study. This isolate developed pale green pigmentation on asparagine medium and released a sweet grape-like odor. Its colony was small, rough, and convex. The isolate was gram negative and showed motility under microscope investigation. The biochemical analysis showed that it had abilities on denitrification, gelatin liquefaction, and starch hydrolysis. It showed positive results in the oxidase and catalase tests. It could use glucose, fructose, and mannitol as carbon source to ferment, resulting in acid production. In addition, the isolate could grow in a temperature range of $30^{\circ} \mathrm{C}$ to $42^{\circ} \mathrm{C}$ and in a $\mathrm{pH}$
Table 1 Morphological, biochemical and cultural characteristics of the selected strain B031

\begin{tabular}{lc}
\hline \multicolumn{1}{c}{ Characteristic } & Observation* \\
\hline Morphology & Pale green \\
Colony color & Small, rough, convex \\
Colony type & Rods \\
Cell shape & Negative \\
Gram staining & + \\
Motility & \\
\hline Biochemistry & + \\
Denitrification & + \\
Gelatin liquefaction & + \\
Starch hydrolysis & + \\
Oxidase test & + \\
Catalase test & \\
Carbon utilization & + \\
Glucose & + \\
Fructose & + \\
Mannitol & + \\
Culture & + \\
Temperature & + \\
$30^{\circ} \mathrm{C}$ & + \\
$37^{\circ} \mathrm{C}$ & + \\
$42^{\circ} \mathrm{C}$ & + \\
pH & + \\
7 & + \\
8 & + \\
\hline
\end{tabular}

Note: ${ }^{*}+$ indicates growth of strain, ${ }^{-}$indicates no growth of strain

range of 5-9. According to Bergey's Manual of Systematic Bacteriology, along with the results of the analyses, the isolate was identified as Pseudomonas aeruginosa (Brenner et al.2005).

\section{Effect of Carbon on Strain Biomass and Biosurfactant Properties}

Table 2 presented the bacterial biomass and characteristics of the biosurfactant produced by Pseudomonas aeruginosa $\mathrm{B} 031$ using different carbon sources, such as glycerol, glucose and n-

Table 2 Effect of carbon source on cell growth, rhamnolipid concentration, emulsion index, surface tension and final pH during biosurfactant production by Pseudomonas aeruginosa $\mathrm{B} 031$

\begin{tabular}{lccccc}
\hline Carbon source & $\begin{array}{c}\text { Biomass } \\
(\mathbf{g} / \mathbf{L})^{*}\end{array}$ & $\mathbf{p H}^{*}$ & $\begin{array}{c}\text { Rhamnose } \\
(\mathbf{m g} / \mathbf{L})^{*}\end{array}$ & $\begin{array}{c}\text { Emulsion index } \\
\mathbf{( \% )}\end{array}$ & $\begin{array}{c}\text { Surface tension } \\
(\mathbf{m N} / \mathbf{m})^{*}\end{array}$ \\
\hline n-hexadecane & $0.3 \pm 0.01^{\mathrm{b}}$ & $5.1 \pm 0.03^{\mathrm{a}}$ & $449 \pm 19^{\mathrm{c}}$ & $20 \pm 0.10 .3^{\mathrm{b}}$ & $37 \pm 0.3^{\mathrm{c}}$ \\
Glycerol & $0.5 \pm 0.02^{\mathrm{a}}$ & $7.0 \pm 0.02^{\mathrm{c}}$ & $718 \pm 15^{\mathrm{d}}$ & $37 \pm 0.2^{\mathrm{a}}$ & $31 \pm 0.2^{\mathrm{b}}$ \\
Glucose & $0.1 \pm 0.01^{\mathrm{c}}$ & $3.4 \pm 0.01^{\mathrm{b}}$ & $180 \pm 11^{\mathrm{a}}$ & $10 \pm 0.1^{\mathrm{c}}$ & $44 \pm 0.1^{\mathrm{a}}$ \\
Control & $0 \pm 0^{\mathrm{d}}$ & $7.2 \pm 0.01^{\mathrm{d}}$ & $0 \pm 0^{\mathrm{b}}$ & $0 \pm 0^{\mathrm{d}}$ & $63 \pm 0^{\mathrm{d}}$ \\
\hline
\end{tabular}

Note: "Data in this table are presented as mean \pm standard deviation. Their values with different superscripts in the same column are significantly different $(\mathrm{P}<0.05)$. 
hexadecane. As observed, the strain was able to use all the evaluated carbon sources to grow and produce biosurfactants. All the carbon sources were found to have significantly influenced bacterial biomass, $\mathrm{pH}$, rhamnose concentration, emulsion index and surface tension.

Among the tested carbon sources, glycerol was found to be the optimum for biosurfactant production of the strain. Its yield was higher than those reported by previous researchers who also used Pseudomonas sp and obtained rhamnolipids (Amani et al. 2013; Sodagari et al. 2018). The highest cell biomass and rhamnose concentration among the observations were $0.5 \mathrm{~g} / \mathrm{L}$ and 718 $\mathrm{mg} / \mathrm{L}$, respectively. These results were expected since glycerol as a carbon source is taken up more easily than the others. On other hand, the use of nhexadecane, which is a very complex and heterogeneous carbon source, resulted in the lowest biomass and biosurfactant yield. Moreover, the biosurfactant yield was lower than the results obtained by Varjani and Upasani (2016) who reported that the Pseudomonas aeruginosa NCIM 5514 strain produced $1.450 \mathrm{mg} / \mathrm{L}$ of rhamnolipid when glycerol was added at $3 \% \mathrm{w} / \mathrm{v}$ as carbon and energy source.

Further, the biosurfactant produced by the strain using glycerol had the highest significant reduction in surface tension and formed a stable emulsion on cultivation media compared with $\mathrm{n}$ hexadecane and glucose $(\mathrm{P}<0.05)$. The surface tension and emulsion index values were $31 \mathrm{mN} / \mathrm{m}$ and $37 \%$, respectively. The use of glycerol also stabilized the $\mathrm{pH}$ condition, whereas the use of glucose and $\mathrm{n}$-hexadecane resulted in a decreased $\mathrm{pH}$. This lower $\mathrm{pH}$ value was probably due to the production of secondary metabolic acid (Müller etal.2012).

Critical micelle concentration (CMC), which indicates the efficiency of a surfactant, is another important characteristic to consider. To measure the CMCs of the biosurfactant under study, culture broths of three treatments (n-hexadecane, glycerol, glucose) were diluted to various extents with a sterile medium and analyzed for surface tensions (Fig. 1). The point of inflection of the curve, which was obtained by measuring the surface tensions of the various dilutions, corresponds to the surfactant concentration equal to CMC. Analysis of the CMCs values of the glycerol, glucose, and $\mathrm{n}$-hexadecane treatments were $35 \mathrm{mN} / \mathrm{m}$, $44 \mathrm{mN} / \mathrm{m}$, and $41 \mathrm{mN} / \mathrm{m}$, respectively $(\mathrm{P}<0.05)$. The lower CMC value of glycerol treatment indicates that glycerol is the most efficient carbon source among the three sources tested (Kłosowska-Chomiczewska et al. 2017). Monteiro et al. (2018) reported that glycerol could be obtained abundantly and cheaply as a byproduct of biodiesel from animal fats and vegetable oil production. Glycerol could be obtained also from trans-esterification of vegetable oils and fossil sources (petroleum, natural gas, coal). Therefore, glycerol is a promising and abundant substrate for biosurfactant production.

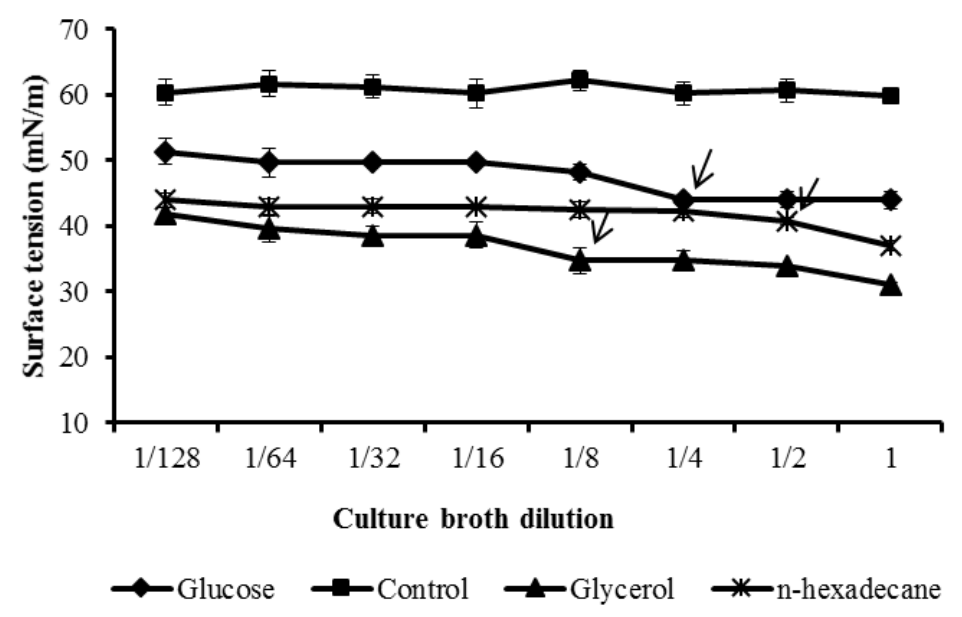

Figure 1 Changes in surface tension in culture broths of Psendomonas aeruginosa B031 at various dilutions using three carbon sources. Arrows correspond to the dilution values that are equal to CMCs. Vertical bars indicate \pm standard deviation of means $(n=3)$. 


\section{Effect of Nitrogen Sources on Strain Biomass and Biosurfactant Properties}

Sodium nitrate was found to be significantly more effective than urea and ammonium chloride $(\mathrm{P}<0.05)$ (Table 3). The data obtained imply that the use of sodium nitrate as nitrogen sources is better for supporting the growth of the strain and stabilizing the $\mathrm{pH}$ of the cultivation medium. These conditions induced a significantly higher surface tension reduction and the formation of a stable emulsion on the cultivation media using sodium nitrate treatment compared with the urea and ammonium chloride treatments $(\mathrm{P}<0.05)$. The results were in accordance with previous studies (Ma et al.2016).

According to Kryachko et al. (2016), the bacteria cell uses nitrates, ammonia, and amino acids as nitrogen sources to produce biosurfactant. During these processes, the $\mathrm{NO}_{3}$ have to be reduced to $\mathrm{NO}_{2}$ and then to $\mathrm{NH}_{3}$. The $\mathrm{NH}_{3}$ can be assimilated either by glutamate dehydrogenase to produce glutamate or, with glutamine, by glutamine synthetase to produce glutamine. Glutamine and $\alpha$-ketoglutarate are then transformed to glutamine by l-glutamine 2 - oxoglutarate aminotransferase. Therefore, in comparison with $\mathrm{NH}_{3}$, the assimilation of $\mathrm{NO}_{3}{ }_{3}$ as a nitrogen source is slower, simulating a nitrogenlimiting condition that is favorable to biosurfactant production (Rizzo et al. 2017).

The evaluation of the CMCs of the culture broths of three treatments (sodium nitrate, urea, and ammonium chloride) shows significant differences among the treatments $(\mathrm{P}<0.05)$ (Fig. 2). The CMC values of the treatments were 24 $\mathrm{mN} / \mathrm{m}$ for sodium nitrate, $35 \mathrm{mN} / \mathrm{m}$ for urea, and $43 \mathrm{mN} / \mathrm{m}$ for ammonium chloride.

The reduction in surface tension and CMC of the biosurfactants is used as primary criterion for selection of biosurfactant-producing microorganisms (Thavasi 2011). This research demonstrated that the crude biosurfactant produced by the strain using glycerol and sodium nitrate as substrates decreased surface tension of the cultivation media by more than $10 \mathrm{mN} / \mathrm{m}$, thus they can be considered good surfactants (Vijayakumar \& Saravanan 2015). As presented in Fig. 1 and 2, surface tension decreased from 42 $\mathrm{mN} / \mathrm{m}$ to a minimum value of $31 \mathrm{mN} / \mathrm{m}$ for the glycerol treatment and from $37 \mathrm{mN} / \mathrm{m}$ to 24

Table 3 Effect of nitrogen source on cell growth, rhamnolipid concentration, emulsion index, surface tension and final pH during biosurfactant production by Psendomonas aeruginosa $\mathrm{B} 031$

\begin{tabular}{lccccc}
\hline Nitrogen source & $\begin{array}{c}\text { Biomass } \\
(\mathbf{g} / \mathbf{L})^{*}\end{array}$ & $\mathbf{p H}^{*}$ & $\begin{array}{c}\text { Rhamnose } \\
(\mathbf{m g} / \mathbf{L})^{*}\end{array}$ & $\begin{array}{c}\text { Emulsion index } \\
\mathbf{( \% )}\end{array}$ & $\begin{array}{c}\text { Surface tension } \\
(\mathbf{m N} / \mathbf{m})^{*}\end{array}$ \\
\hline $\mathrm{Urea}$ & $1.8 \pm 0.01^{\mathrm{a}}$ & $6.8 \pm 0.01^{\mathrm{a}}$ & $220 \pm 19^{\mathrm{c}}$ & $28 \pm 0.06^{\mathrm{a}}$ & $35 \pm 0.04^{\mathrm{a}}$ \\
$\mathrm{NH}_{4} \mathrm{Cl}$ & $1.0 \pm 0.01^{\mathrm{b}}$ & $4.8 \pm 0.02^{\mathrm{b}}$ & $90 \pm 15^{\mathrm{d}}$ & $17 \pm 0.2^{\mathrm{b}}$ & $42 \pm 0.5^{\mathrm{b}}$ \\
$\mathrm{NaNO}_{3}$ & $2.5 \pm 0.02^{\mathrm{c}}$ & $7.3 \pm 0.01^{\mathrm{c}}$ & $290 \pm 11^{\mathrm{a}}$ & $30 \pm 0.1^{\mathrm{c}}$ & $24 \pm 0.1^{\mathrm{c}}$ \\
$\mathrm{Control}$ & $0 \pm 0^{\mathrm{d}}$ & $7.2 \pm 0.01^{\mathrm{c}}$ & $0 \pm 0^{\mathrm{b}}$ & $0 \pm 0^{\mathrm{d}}$ & $63 \pm 0^{\mathrm{d}}$ \\
\hline
\end{tabular}

Note: $*$ Data in this table are presented as mean \pm standard deviation. Their values with different superscripts in the same column are significantly different $(\mathrm{P}<0.05)$

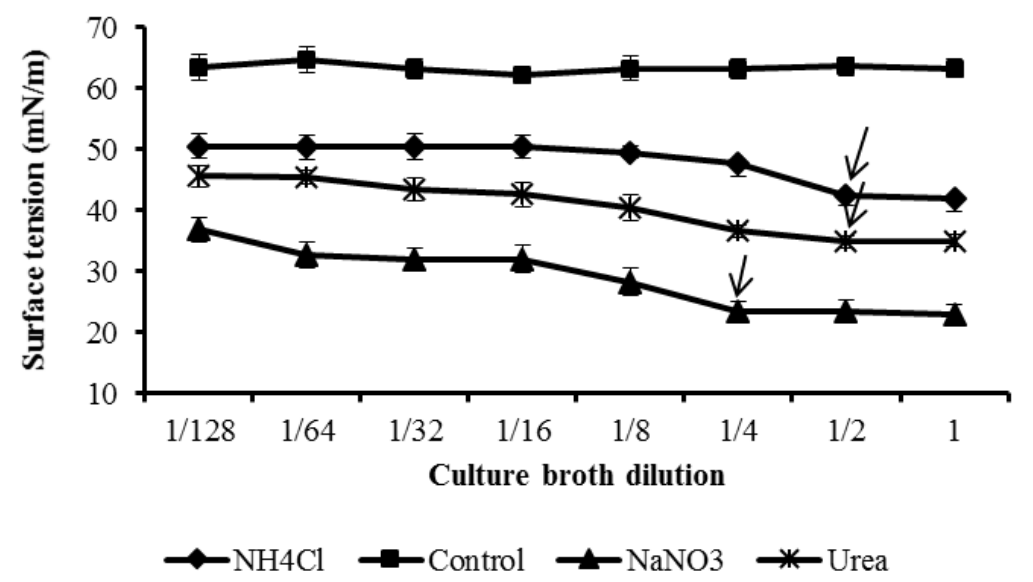

Figure 2 Changes in the surface tension of culture broths of Psendomonas aruginosa B031 at various dilutions using three nitrogen sources. Arrows correspond to the dilution values that are equal to CMCs. Vertical bars indicate \pm standard deviation of means $(n=3)$. 
$\mathrm{mN} / \mathrm{m}$ for the sodium nitrate treatment. These capacities are comparable to the outcomes of similar previous research wherein surface tension was reduced to a minimal value of $27-28 \mathrm{mN} / \mathrm{m}$ (Petrikov et al. 2013). Other studies had been carried out also on biosurfactants by $P$. fluorescens, for which the minimal value of surface tension was $27.5 \mathrm{mN} / \mathrm{m}$ (İkizler et al. 2017). Therefore, this study showed that both glycerol and sodium nitrate are efficient and promising substrates for biosurfactant production from Pseudomonas aruginosa $\mathrm{B} 031$.

\section{Application of Biosurfactants in Hydro- carbon Removal}

An increasing number of sites have been polluted by hydrocarbons become a seriously effect to ecosystem and human health critical. For removing these pollutions, environmentally and low-cost technology was highly required. Because oil has low water solubility, which increase its sorption by soil particles, researchers have been exploring the use of biosurfactants to accelerate hydrocarbon removal from the contaminated sites (Arslan et al.2017).

The use of crude biosurfactant to remove hydrocarbon contaminants is common in bioremediation technologies. Therefore, this study investigated the application of the biosurfactant from P. aeruginosa B031 in its crude form, without prior costly extraction or purification steps. The experiment used cell-free supernatant containing the crude biosurfactant and chemical surfactants (SDS and Triton X-100) to verify the former's capacity to remove crude oil from sand samples.

The biosurfactant produced $P$. aeruginosa $\mathrm{B} 031$, SDS, Triton X-100, and distilled water (control) showed significantly different $(\mathrm{P}<0.05)$ capabilities in removing crude oil from contaminated sand (Table 4). The crude biosurfactants from both glycerol and sodium nitrate treatments yielded higher values $(87.5 \%$ and $84 \%$, respectively), but no significant difference $(\mathrm{P}<0.05)$ was observed between them. The removals obtained by SDS and Triton X-100 as synthetic surfactants at the same concentration were lower (73\% and $71.6 \%$, respectively), which that of distilled water (control) was only $30.2 \%$. The results imply that the cell-free supernatant containing the crude biosurfactant was practically as effective as the isolated biosurfactant in removing crude oil, indicating the possible use of the unpurified biosurfactant to minimize production costs.

The ability of biosurfactants to remove crude oil can be explained as follows: biosurfactants promote the transport of hydrophobic contaminants toward an aqueous phase through some particular interactions, resulting in emulsification and micellization, thus leading to their removal (Costa et al. 2010). The results of the experiments indicate that these biosurfactants are more effective in oil recovery than the chemical surfactants (SDS or Triton X-100). These results were in accordance with the results of Lai et al. (2009) who observed that biosurfactants such as rhamnolipids and surfactin are more efficient in removing hydrocarbon than Tween-800 and Triton X-100. Therefore, these biosurfactants indicate good prospects for applications, especially for bioremediation.

\section{CONCLUSION}

The biosurfactant produced by Psendomonas aeruginosa $\mathrm{B} 031$ was found to produce the highest biomass and the best surface-activities and emulsification properties when glycerol and sodium nitrate were used as carbon and nitrogen sources, respectively. The crude biosurfactants

Table 4 Comparison of the hydrocarbon removal ability of the crude bacterial biosurfactant, SDS, Triton X-100 and distilled water (control)

\begin{tabular}{lc}
\hline \multicolumn{1}{c}{ Sample } & Crude oil removal (\%) \\
\hline Crude bacterial biosurfactant from glycerol treatment & $87.5^{\mathrm{d}}$ \\
Crude bacterial biosurfactant from $\mathrm{NaNO}_{3}$ treatment & $84 . \pm^{\mathrm{a}} 6^{\mathrm{d}}$ \\
SDS & $73.0 \pm 3^{\mathrm{b}}$ \\
Triton X-100 & $71.6 \pm 2^{\mathrm{c}}$ \\
Distilled water (control) & $30.2^{\mathrm{a}}$ \\
\hline
\end{tabular}

Note: $*$ Data in this table are presented as mean \pm standard deviation. Their values with different superscripts in the same column are significantly different $(\mathrm{P}<0.05)$. 
produced by the strain were able to efficiently decrease the interfacial tension of culture broth dilution. These biosurfactants were capable of efficiently removing crude oil from sand samples, performing better than chemical surfactants, thus hold promise for hydrocarbon bioremediation application.

\section{ACKNOWLEDGEMENTS}

We acknowledge financial support from BOPTN 2015 Research Grant of Faculty of Biology, Universitas Gadjah Mada, Yogyakarta, Indonesia (Contract Number: UGM/BI/2460/ $\mathrm{UM} / 03 / 02)$. Authors also thank Ms Sofianingtyas for her help in preparing the strain.

\section{REFERENCES}

Agbogidi MO, Dolor ED, Okechukwu EM. 2007. Evaluation of Tectona grandis (Linn.) and Gmelina arborea (Roxb.) for phytoremediation in crude oil contaminated soils. Agric Conspec Sci 72(2):149-52.

Al-Bahry SN, Al-Wahaibi YM, Elshafie AE, Al-Bemani AS, Joshi SJ, Al-Makhmari HS, Al-Sulaimani HS. 2013. Biosurfactant production by Bacillus subtilis B20 using date molasses and its possible application in enhanced oil recovery. Int Biodeterior Biodegradation 81:141-6.

Amani H, Müller MM, Syldatk C, Hausmann R. 2013. Production of microbial rhamnolipid by Psendomonas aeruginosa MM1011 for ex situ enhanced oil recovery. Appl Biochem Biotechnol 170:1080-93.

Aparna A, Srinikethan G, Smitha H. 2012. Production and characterization of biosurfactant produced by a novel Psendomonas sp. 2B. Colloids Surf B 95:23-9.

Arslan G, Kipcak E, Dirik C, Aktu T, Peker S. 2017. Surface adsorption and spontaneous aggregation of rhamnolipid mixtures in aqueous solutions. Colloids Surfaces A Physicochem Eng As 519:125-36.

Barakat KM, Hassan SWM, Darwesh OM. 2017. Biosurfactant production by haloalkaliphilic Bacillus strains isolated from Red Sea, Egypt. Egypt J Aquat Res 43:205-11.

Brenner DJ, Krieg NR, Staley JR. 2005. Bergey's manual systematic bacteriology. New York (US): Springer.

Burgos-Díaz C, Pons R, Teruel JA, Aranda FJ, Ortiz A, Manresa AM, Marqués J. 2013. The production and physicochemical properties of a biosurfactant mixture obtained from Sphingobacterium detergens. Colloid Interface Sci 394:368-79.

Calvo C, Manzanera M, Silva-Castro GA, Uad I, GonzálezLópez J. 2009. Application of bioemulsifiers in soil oil bioremediation processes. Future prospects Sci Total Environ 407:3634-40.

Cheng F. 2013. Characterization of a blend-biosurfactant of glycolipid and lipopeptide produced by Bacillus subtilis TU2 isolated from underground oilextraction wastewater. J Microbiol Biotechnol 23:390-6.

Costa SGVAO, Nitschke M, Lépine F, Déziel E, Contieroa J. 2010. Structure, properties and applications of rhamnolipids produced by Pseudomonas aeruginosa L21 from cassava wastewater. Process Biochem 45:1511-6.

Cristaldi A, Conti GO, Jho EH, Zuccarello P, GrassoA, Copat C, Ferrante M. 2017. Phytoremediation of contaminated soils by heavy metals and PAHs. A brief review. Environ Technol Innov 8:309-26.

Deepika KV, Kalam S, Sridhar PR, Podile AR, Bramhachari PV. 2016. Optimization of rhamnolipid biosurfactant production by mangrove sediment bacterium Psendomonas aeruginosa KVD-HR42 using response surface methodology. Biocatal Agric Biotechnol 5:38-47.

Fatima K, Imran A, Amin I, Khan QM, Afzal M. 2018. Successful phytoremediation of crude-oil contaminated soil at an oil exploration and production company by plants-bacterial synergism. Int J Phytoremediation 20:675-81.

Geetha SJ. Banat IM, Joshi SJ. 2018. Biosurfactants: Production and potential applications in microbial enhanced oil recovery (MEOR). Biocat Agric Biotechnol 14:23-32.

Guo M, Gong Z, Miao R, Rookes J, Cahill D, Zhuang J. 2017. Microbial mechanisms controlling the rhizosphere effect of ryegrass on degradation of polycyclic aromatic hydrocarbons in an agedcontaminated agricultural soil. Soil Biol Biochem 113:130-42.

Hassanshahian M, Emitazi G. 2008. Investigation of alkane biodegradation using the microtiter plate method and correlation between biofilm formation, biosurfactant production and crude oil biodegradation. Int Biodeterior Biodegrad 62:1708.

Hou J, Liu W, Wang B, Wang Q, Luo Y, Franks AE. 2015. PGPR enhanced phytoremediation of petroleum contaminated soil and rhizosphere microbial community response. Chemosphere 138:592-8.

İkizler B, Arslan G, Kipcak E, Dirik C Çelenk D, Aktuğlu T, ... Peker S. 2017. Surface adsorption and spontaneous aggregation of rhamnolipid mixtures in aqueous solutions. Colloids and Surfaces A: Physicochem Eng Aspects 519:125-36.

Janek T, Lukaszewicz M, Rezanka M, Krasowska A. 2010. Isolation and characterization of two new lipopeptide biosurfactants produced by Pseudomonas fluorescens BD5 isolated from water from Arctic 
Archipelago of Svaldbard. Biores Technol 101:6118-23.

Joshi PA, Shekhawat DB. 2014. Screening and isolation of biosurfactant producing bacteria from petroleum contaminated soil. Eur J Exp Biol 4:164-9.

Khan S, Afzal M, Iqbal S, Khan QM. 2013. Plant-bacteria partnerships for the remediation of hydrocarbon contaminated soils. Chemosphere 90:1317-32.

Kłosowska-Chomiczewska IE, Mędrzycka K, Hallmann E, Karpenko E, Pokynbroda T, Macierzanka A, Jungnickel C. 2017. Rhamnolipid CMC prediction. J Colloid Interface Sc 488:10-9.

Kong Q, Wang Z, Niu P, Miao M. 2016. Greenhouse gas emission and microbial community dynamics during simultaneous nitrification and denitrification process. Bioresour Technol 210:94-100.

Kryachko Y, Semler D, Vogrinetz J, Lemke M, Links MG, Mccarthy EL, ... Hemmingsen SM. 2016. Enrichment and identification of biosurfactantproducing oil field microbiota utilizing electron acceptors other than oxygen and nitrate. J Biotechnol 231:9-15.

Lai C, Huang YC, Wei YH, Chang JS. 2009. Biosurfactantenhanced removal of total petroleum hydrocarbons from contaminated soil. J Hazard Mater 167:609-14.

Liu Q, Lin J, Wang W, Huang H, Li S. 2015. Production of surfactin isoforms by Bacillus subtilis BS-37 and its applicability to enhanced oil recovery under laboratory conditions. Biochem EngJ 93:31-7.

Ma KY, Sun MY, Dong W, He CQ, Chen FL, Ma YL. 2016. Effects of nutrition optimization strategy on rhamnolipid production in a Pseudomonas aeruginosa strain DN1 for bioremediation of crude oil. Biocatal Agric Biotechnol 6:144-51.

Ma Z, Liu J, Dick RP, Li H, Shen D, Gao Y, ... Ling W. 2018. Rhamnolipid influences biosorption and biodegradation of phenanthrene by phenanthrenedegrading strain Pseudomonas sp. Ph6. Environ Poll 240:359-67.

Mnif I, Ghribi D. 2015. High molecular weight bioemulsifiers, main properties and potential environmental and biomedical applications. World J Microbiol Biotechnol 31:691-706.

Monteiro MR, Kugelmeier CL, Pinheiro RS, Batalha MO, da Silva César A. 2018. Glycerol from biodiesel production: Technological paths for sustainability. Renew Sustain Energy Rev 88: 109-22.

Moya RI, Tsaousi K, Rudden M, Marchant R, Alameda EJ, García RM, Banat IM. 2015. Rhamnolipid and surfactin production from olive oil mill waste as sole carbon source. Bioresour Technol 198:231-6.

Müller MM, Kügler JH, Henkel M, Gerlitzki M, Hörmann B, Pöhnlein M, ... Hausmannb R. 2012. Rhamnolipids-Next Generation Surfactants? J Biotechnol 162:366-80.
Pacwa-Płociniczak M, Płaza GA, Piotrowska-Seget Z, Cameotra SS. 2011. Environmental applications of biosurfactants: Recent advances. Int J Mol Sci 12:633-54.

Panjiar N, Sachan SG, Sachan A. 2015. Screening of bioemulsifier-producing microorganisms isolated from oil-contaminated sites. Ann microbial 65:75364.

Patowary R, Patowary K, Chandra Kalita M, Deka S. 2018. Application of biosurfactant for enhancement of bioremediation process of crude oil contaminated soil. Int Biodeterior Biodegradation 129:50-60.

Petrikov K, Delegan Y, Surin A, Ponamoreva O, Puntus I, Filonov A, Boronin A. 2013. Glycolipids of Pseudomonas and Rhodococcus oil-degrading bacteria used in bioremediation preparations: Formation and structure. Process Biochem 48:31-5.

Rizzo MG, Chines V, Franco D, Nicolò MS, Guglielmino SPP. 2017. The role of glutamine in Pseudomonas mediterranea in biotechnological processes. New Biotechnol 37:144-51.

Rufino RD, Luna JM, Sarubbo LA, Rodrigues LRM, Teixeira JAC, Campos-Takaki GM. 2011. Antimicrobial and anti-adhesive potential of a biosurfactant Rufisan produced by Candida lipolytica UCP 0988. Colloids Surf B 84:1-5.

Sakthipriya N, Doble M, Sangwai JS. 2015. Biosurfactant from Pseudomonas species with waxes as carbon source - Their production, modeling and properties. J Ind Eng Chem 31:100-11.

Seedevi P, Moovendhan M, Sudharsan S, Sivasankar P, Sivakumar L, Vairamani S, Shanmugam A. 2018. Isolation and chemical characteristics of rhamnose enriched polysaccharide from Grateloupia lithophila. Carbohydr Polym 195:486-94.

Shavandi M, Mohebali G, Haddadi A, Shakarami H, Nuhi A. 2011. Emulsification potential of a newly isolated biosurfactant-producing bacterium, Rhodococcus sp. strain TA6. Colloids Surf B 82:47782.

Sodagari M, Invally K, Ju LK. 2018. Maximize rhamnolipid production with low foaming and high yield. Enzyme Microb Technol 110:79-86.

Thavasi R. 2011. Microbial biosurfactants: From an environmental application point of view. J Bioremediat Biodegrad 2:104-12.

Thavasi R, Sharma S, Jayalakshmi S. 2011. Evaluation of screening methods for the isolation of biosurfactant producing marine bacteria. J Pet Environ Biotechnol S1:1-6.

Thorsen MK, Brandt KK, Nybroe O. 2013. Abundance and diversity of culturable Pseudomonas constitute sensitive indicators for adverse long-term copper impacts in soil. Soil Biol Biochem 57:933-5. 
Varjani SJ. 2017. Microbial degradation of petroleum hydrocarbons. Bioresour Technology 223:277-86.

Varjani SJ, Upasani VN. 2016. Carbon spectrum utilization by an indigenous strain of Pseudomonas aeruginosa NCIM 5514: Production, characterization and surface active properties of biosurfactant. Bioresour Technology 221:510-6.

Villalobos M, Avila-Forcada AP, Gutierrez-Ruiz ME. 2008. Improved gravimetric method to determine total petroleum hydrocarbons in contaminated soils. Water Air Soil Pollut 194:151-61.

Vinogradov E, Sadovskaya I, Grard T, Chapot-Chartier MP. 2016. Structural studies of the rhamnose-rich cell wall polysaccharide of Lactobacillus casei BL23. Carbohydr Res 435:156-61.

Vijayakumar S, Saravanan V. 2015. Biosurfactants-types, sources and applications. Research J Microbiology 10:181-92.

Yenn R, Borah M, Boruah HD, Roy AS, Baruah R, Saikia N, Tamuli AK. 2014. Phytoremediation of abandoned crude oil contaminated drill sites of assam with the aid of a hydrocarbon-degrading bacterial formulation. Int J Phytoremediation 16:909-25.

Zdziennicka A, Jańczuk B. 2018. Wetting and adhesion properties of rhamnolipid and surfactin. Int J Adhesion Adhesives 84:275-82. 